\title{
Wybrane przykłady komercjalizacji symboli narodowych \\ i patriotycznych w Polsce
}

Trend noszenia odzieży i akcesoriów patriotycznych nie jest zależny od kondycji intelektualnej i materialnej, a skorelowany jest przede wszystkim z poglądami w sferze aksjologicznej poszczególnych osób. Mając na uwadze szeroko rozumiany patriotyzm, Polacy, szczególnie młodzi, czują potrzebę manifestacji swoich preferencji, poglądów czy upodobań. Wykorzystują w tym celu odzież i akcesoria patriotyczne. W niniejszym artykule uwaga została skupiona na dwóch głównych markach odzieżowych Red is Bad oraz Surge Polonia, a także na kolekcji projektanta Roberta Kupisza, znanej pod nazwą Heroes. Ponadto - jako kontekst kulturowy - przeanalizowana została kontrowersyjna kolekcja Arkadiusa Maryja Dziewica nosi spodnie, kontestująca ważne w kulturze polskiej motywy religijne. Opisano także działalność społeczną wspomnianych firm odzieżowych. Niezwykle istotne było zbadanie, czy tylko czerpią one zysk z wykorzystywania symboli patriotycznych, wizerunku bohaterów i wydarzeń historycznych, czy może czują się również zobowiązane do niesienia pomocy, na przykład kombatantom. Ostatnim punktem pracy są rozważania na temat inflacji symboli patriotycznych we współczesnej Polsce. Określono w nim niebezpieczeństwa związane z wykorzystywaniem symboli patriotycznych w produktach handlowych.

\section{Kolekcja Arkadiusa Maryja Dziewica nosi spodnie}

Gra designerów i stylistów z narodowymi (i religijnymi) symbolami ma swoją historię. Kontrowersyjna w odbiorze kolekcja Arkadiusa Maryja Dziewica nosi spodnie 
(2003) łączyła w sobie motywy religijne w postaci krucyfiksów, różańców i wizerunku Madonny. W świadomości wielu osób użycie tego typu grafiki i elementów stricte sakralnych było w Polsce niedopuszczalne. Modelki z namalowanym na nagim ciele obrazem Matki Boskiej lub wykreowane na jej wzór to tylko nieliczne z metod wykorzystanych przez Arkadiusa do przykucia uwagi widowni. Twórca za pomocą takich środków przekazu chciał „pokazać, jak rozpętywanie konfliktów w imię religii wpływa destrukcyjnie na ludzki gatunek"1.

Kolekcja dedykowana na wiosnę/lato 2002 okazała się bardzo odważna w wykorzystaniu symboli religijnych z całego świata, czego przykład stanowi performance artysty polegający na rozchyleniu kokonu, w który był odziany. W jego wnętrzu znajdowały się kolejne symbole kojarzone z religiami świata. Premierowy pokaz zbiegł się w czasie z atakami terrorystycznymi na World Trade Center, przez co kolekcja nabrała wymiaru symbolicznego ${ }^{2}$.

Poruszanie społecznie trudnych tematów, często z pogranicza świata polityki, było domeną Arkadiusa. W jednym z wywiadów powiedział on:

99\% świata mody nie interesują tematy społeczne czy polityczne. To biznes, a więc większość projektantów robi modę tylko po to, aby na niej zarabiać. Zapominają, że moda może także nieść przekaz. [...] Dla mnie jest ona formą ekspresji artystycznej. Wyrażam w niej to, co mnie boli, co mnie cieszy, co lubię i to, czego nienawidzę $e^{3}$.

\section{Kolekcja Roberta Kupisza Heroes (zima 2012)}

Kolekcja stworzona przez projektanta odzieży Roberta Kupisza pod nazwą Heroes (z ang. bohaterowie) zainspirowana została twórczością Krzysztofa Kamila Baczyńskiego i odwoływała się bezpośrednio do powstania warszawskiego. Jej motywem przewodnim była grafika obrazująca Orła Białego, umiejscawiana przede wszystkim na koszulkach i opaskach. Poprzez wykorzystanie symboli narodowych autor kolekcji, wstrząśnięty wydarzeniami zapoczątkowanymi w sierpniu 1944 roku, chciał przybliżyć młodym Polakom historię narodu i jej bohaterów. Podjęcie tak ważnej i trudnej tematyki historycznej i patriotycznej miało uzmysłowić nastoletnim Polakom, do jakich wzorców powinni sięgać. Ubrania miały zachęcić do refleksji i wywołać poczucie dumy z noszenia na piersi tego samego symbolu, za który rówieśnicy odbiorców kolekcji ginęli w powstaniu warszawskim. Sam autor mówił w wywiadzie dla

1 Arkadius, Maryja Dziewica nosi spodnie, http://culture.pl/pl/dzielo/arkadius-maryja-dziewica-nosi-spodnie (dostęp: 31 maja 2017).

2 Ibidem.

3 Arkadius: wolę umrzeć niż pójść na korporacyjny kompromis!, http://mmfreestyle.com/arkadiuswole-umrzec-niz-pojsc-na-korporacyjny-kompromis/ (dostęp: 31 maja 2017). 
„Wysokich Obcasów”: „Chciałem zrobić pokaz mody. Chciałem historię podrasować tak, żeby współczesność była dla młodych ludzi pomostem do zrozumienia tematu"".

Pokaz kolekcji Heroes przeniósł uczestników wydarzenia w czasy wojenne. Modele wcielili się w role młodych powstańców walczących o Warszawę. Dziewczyny z mozolnie zaplecionymi warkoczami zwieńczonymi kokardami czy młodzieńcy z tornistrami byli elementem lekcji historii. Widocznym w kolekcji akcentem jest bunt, manifestowany w niedbale zarzuconych okryciach, sfatygowanych swetrach czy włączeniu elementów skóry lub współczesnych form. Projektant zapewne chciał wyrazić w ten sposób sprzeciw wobec opresji doświadczanej przez powstańców. Pokaz okazał się przełomem w karierze kreatora mody. Został doskonale przyjęty przez świat mody oraz zwykłych ludzi, o czym świadczy przeniknięcie trendu patriotycznego do mody ulicznej.

Mimo że kolekcja składała się w większości z okryć wierzchnich, przełamanych dzianinowymi szalami, jedwabnymi sukienkami czy flanelowymi koszulami, najbardziej popularny stał się T-shirt z nadrukiem Orła Białego. Sama koszulka była sprana i rozciągnięta, a widniejący na niej symbol w różnym stopniu naruszony, jednak zawsze umiejscowiony w centralnym punkcie ubrania. Wszystkie elementy kolekcji utrzymane były w czerniach, szarościach, beżach i granatach, co doskonale podkreślało klimat wojennych czasów. Kupisz chciał sprawić, aby młodzież polubiła polskie symbole, poznała bohaterów i nie musiała sięgać po wielkie postaci z innych krajów, ponieważ historia Polski ma ich dostatecznie wielu ${ }^{5}$.

Wspomniana wcześniej koszulka z motywem Orła Białego zdobyła wyjątkową popularność. Można w niej było zobaczyć ludzi związanych z show-biznesem, to jest aktorów, muzyków, a nawet dziennikarzy. Jeszcze większy rozgłos przedmiotowej kolekcji nadało wystąpienie w wyżej wymienionej koszulce jednej z celebrytek przybyłych na mecz Polska-Czechy rozgrywany w ramach turnieju Euro 2012.

\section{Marki produkujące odzież i akcesoria patriotyczne — Red is Bad}

Kultura popularna ma własnych designerów patriotyzmu. Firma stworzona przez dwóch kolegów z liceum - Kubę Iwańskiego i Pawła Szopę, zajmuje się produkcją odzieży, gadżetów i akcesoriów o tematyce historyczno-patriotycznej. „Red is Bad to polska marka odzieży patriotycznej dla ludzi ceniących wolność i dumnych z polskiej

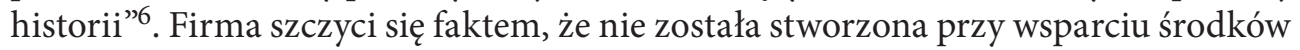
unijnych lub programów państwowych. W swojej ofercie ma szeroką gamę ubrań,

4 S. Kulej, Robert Kupisz: Godło na topie, http://www.wysokieobcasy.pl/wysokie-obcasy /1,96856,11066026,Robert_Kupisz__Godlo_na_topie.html?disableRedirects=true (dostęp: 27 maja 2017).

5 https://robertkupisz.com/pl/collections/heroes-winter-2012-13 (dostęp: 26 maja 2017).

${ }^{6}$ Oficjalna strona Red is Bad, https://www.redisbad.pl (dostęp: 30 maja 2017). 
począwszy od spodenek i legginsów, po koszulki i bluzy przeznaczone dla przedstawicieli obu płci. Właściciele Red is Bad podkreślają, że ważne są dla nich polska tradycja i wartości patriotyczne, ponad wszystko cenią bogatą historię państwa oraz jej bohaterów. To ich sylwetki są głównym motywem w grafikach umieszczanych na odzieży. Poza postaciami nadruki przedstawiają polskie symbole narodowe oraz istotne wydarzenia historyczne. Ubrania mają w pewnym stopniu kształtować tożsamość użytkowników.

Jednym z klientów marki jest Prezydent Rzeczypospolitej Polskiej Andrzej Duda, który podczas lotu do Chińskiej Republiki Ludowej w 2015 roku został sfotografowany w czarnej koszulce z niewielkim motywem polskiej flagi na lewej piersi. Sprawa wzbudziła wiele kontrowersji między innymi dlatego, że nazwa firmy oznacza „czerwone jest złe", a koszulkę włożyła głowa państwa w drodze z oficjalną wizytą do Chin, w których panuje ustrój komunistyczny, kojarzony w krajach Europy Wschodniej i Środkowej z kolorem czerwonym ${ }^{7}$.

Burzę medialną wywołała także współpraca marki z producentem wód mineralnych. Przedmiotem wspólnych działań było wprowadzenie do sprzedaży butelek wody opatrzonych etykietą inspirowaną barwami narodowymi z okazji przypadającego 2 maja Dnia Flagi Rzeczypospolitej Polskiej. Większość internautów o pomyśle kooperacji wypowiadała się w sposób negatywny ${ }^{8}$. Woda została określona mianem „brutalnej” lub „politycznej”. Taki oddźwięk kampanii zaskoczył właścicieli rozlewni wody. W wydanym oświadczeniu tłumaczyli oni, że nie chcą być w żaden sposób uwikłani w działania światopoglądowe kontrahenta, a projekt wspólnie przez nich stworzony jest dziełem wyłącznie biznesowym odwołującym się do tradycji i historii ${ }^{9}$.

Kontrowersje wzbudziła również wprowadzona przez brand kolekcja ubrań promowana pod nazwą Goodbye Mr. Marx. Kampania reklamowa linii oparta została na fotografiach przedstawiających młodych ludzi drących strony publikacji autorstwa Karola Marksa, mielących je w maszynce do mięsa na tle meblościanki w PRL-owskim stylu czy malujących czerwoną farbą popiersie filozofa. W asortymencie kolekcji można znaleźć między innymi koszulki z grafiką przedstawiającą czołg strzelający do głów Marksa utrzymanych w stylistyce gry komputerowej czy z wize-

7 Prezydent Duda leciat do Chin w koszulce marki Red is Bad. Reklama, „żenada”, czy dobry pomyst, http://wiadomosci.gazeta.pl/wiadomosci/1,114871,19241587,prezydent-duda-lecial-do-chin-w-koszulce-marki-red-is-bad.html (dostęp: 8 czerwca 2017).

8 Staropolanka i Red is Bad przygotowały limitowana edycje wody, http://www.bankier.pl/wiadomosc/Staropolanka-i-Red-is-Bad-przygotowaly-limitowana-edycje-wody-7514939.html (dostęp: 8 czerwca 2017).

9 Patriotyczna woda mineralna wywołała burzę w internecie. „Staropolanka” współpracuje z markq odzieży patriotycznej „Red is Bad”, http://wpolityce.pl/spoleczenstwo/338151-patriotyczna-wodamineralna-wywolala-burze-w-internecie-staropolanka-wspolpracuje-z-marka-odziezy-patriotycznejred-is-bad (dostęp: 8 czerwca 2017). 
runkiem Pacmana (bohatera komputerowej gry zręcznościowej z lat osiemdziesiątych $\mathrm{XX}$ wieku) pożerającego głowę myśliciela. Reszta kolekcji przesiąknięta była modnym w Polsce w czasach komunizmu wzorem pepitki w różnych kolorach.
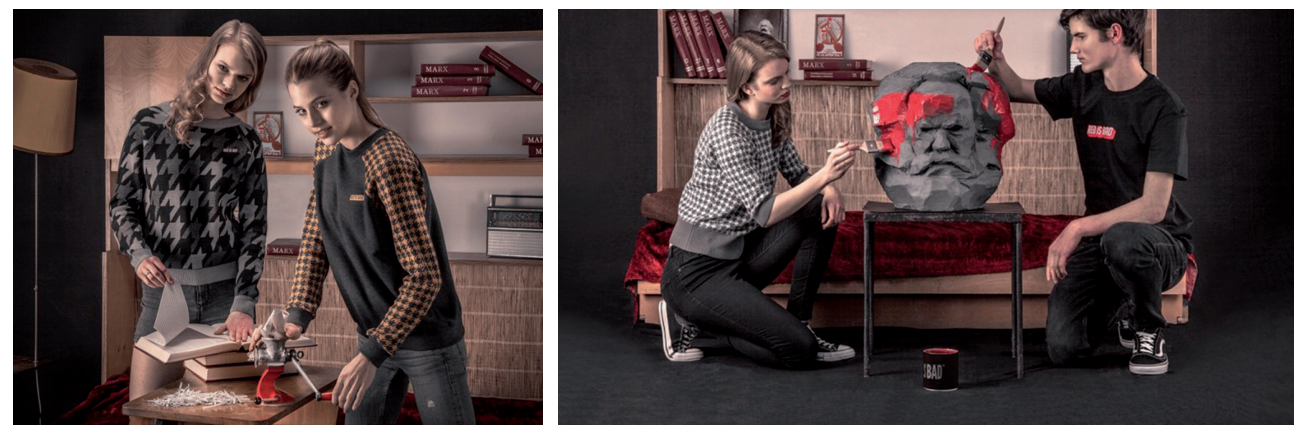

Ilustracja 1. Zdjęcia z kampanii promującej kolekcję Goodbye Mr. Marx

Źródło: oficjalna strona Red is Bad, https://www.redisbad.pl/goodbye-mr-marx (dostęp: 8 czerwca 2017).

\section{Marki produkujące odzież i akcesoria patriotyczne — Surge Polonia}

Surge Polonia! (z łac. Powstań, Polsko!) to zawołanie widniejące na sztandarze 1 Samodzielnej Brygady Spadochronowej, którą podczas operacji Market Garden w 1944 roku dowodził generał Stanisław Sosabowski ${ }^{10}$. Taką nazwę obrała wrocławska firma produkująca odzież patriotyczną. Jej twórcy podkreślają, że jest to pierwsze na świecie tego typu przedsiębiorstwo. Powstałą w 2011 roku markę tworzy kilkoro przyjaciół z zamiłowaniem do historii, którzy tak ujmują swój cel: „Chcemy promować ideę nowoczesnego patriotyzmu oraz dowieść, że patriotyzm może być zarówno ciekawy, jak i niezwykle inspirujący" ${ }^{\prime 1}$. Pomysł na założenie biznesu zrodził się z niedostępności ciekawych i dobrych jakościowo ubrań o tematyce patriotyczno-historycznej. Wzornictwo inspirowane wydarzeniami, postaciami lub symbolami znanymi z historii Polski tworzone jest przez młodych designerów, którzy w swojej pracy nawiązują na przykład do street artu i komiksu. Właściciele marki podkreślają, że proces tworzenia odzieży od początku do końca przebiega w Polsce, a dokładniej w Łodzi. W ten sposób firma wspiera gospodarkę krajową przez tworzenie nowych miejsc pracy w odradzającym się przemyśle tekstylnym ${ }^{12}$.

10 O marce, https://surgepolonia.pl/O-MARCE-cabout-pol-3.html (dostęp: 1 czerwca 2017).

11 Oficjalna strona Surge Polonia, https://surgepolonia.pl/ (dostęp: 1 czerwca 2017).

12 J. Pachla, Przed Wami Surge Polonia. Wrocławska marka odzieży patriotycznej, która podbija rynek!, http://wroclaw.eska.pl/poznaj-miasto/przed-wami-surge-polonia-wroclawska-marka-odziezypatriotycznej-ktora-podbija-rynek-galeria/108598 (dostęp: 4 czerwca 2017). 
Firma oferuje koszulki, kurtki, bluzy, pasy i wszelkiego rodzaju dodatki w formie saszetek, breloków, futerałów na telefony, toreb i kalendarzy. Wszystkie rzeczy dostępne są w kilku liniach produktowych, różnych wzorach i rozmiarach.

Na odzieży i dodatkach umieszczane są motywy graficzne kojarzone z powstaniem warszawskim, Armią Krajową czy żołnierzami wyklętymi. Ubrania opatrzone są także takimi symbolami patriotycznymi, jak Polska Walcząca, krzyż kawalerski uznawany za symbol husarii lub Orzeł Biały. Do wymienionych wyżej motywów dołączyły również wymowne hasła: „I speak Polish. What's your superpower?”, co w wolnym tłumaczeniu oznacza „Mówię po polsku, a jaka jest Twoja supermoc?” Jest to zapewne nawiązanie do powszechnie przyjętego przekonania o wysokim stopniu trudności języka polskiego, rozumianego w tym ujęciu jako coś nobilitującego posługujących się nim ludzi. Na kolejnej koszulce można przeczytać: „Poczuj dumę”, w domyśle $\mathrm{z}$ bycia Polakiem, z narodowej historii lub z noszenia odzieży tej marki. Na innej widnieje napis: „Nigdy się nie Poddawaj” z wykorzystaniem symbolu Polski Walczącej zamiast litery „P”. Użycie w tym kontekście znaku zamiast litery wyraźnie nawiązuje do waleczności powstańców warszawskich. W ofercie sklepu można również znaleźć T-shirty z prostym nadrukiem „Made in Poland”, „Patriotka” albo „Polska”.

Czołowym celem marki jest nowoczesny sposób popularyzacji polskiej historii oraz symboli, a także gloryfikowanie zwycięstw. Upamiętnianie zapomnianych bohaterów w kreatywnych grafikach i designerskie podejście do tematu patriotyzmu znalazło wielu fanów. Zespół Surge Polonia utrzymuje, że bierze czynny udział w rozmowach $\mathrm{z}$ klientami dotyczących wyboru kolejnych motywów wprowadzanych do $\operatorname{produkcji}^{13}$.

\section{Popularne motywy graficzne}

Jeden z trzech symboli państwa polskiego według Ustawy z dnia 31 stycznia $1980 \mathrm{r}$. o godle, barwach i hymnie Rzeczypospolitej Polskiej oraz o pieczęciach państwowych to barwy narodowe. Obowiązkiem, ale również prawem każdego Polaka jest czczenie i poszanowanie wszystkich symboli wymienionych w ustawie. Kolory narodowe w artykułach 4 i 5 uściślone są jako biały i czerwony, w pozycji poziomej, w dwóch pasach tej samej szerokości - górny jest biały, a dolny czerwony. Stanowią one flagę Rzeczypospolitej Polskiej, z której wszyscy obywatele mogą korzystać, aby podkreślić rangę uroczystości, wyróżnić ważne wydarzenie lub święto ${ }^{14}$. Kolejny wymieniony w ustawie symbol, który pozostaje pod specjalną ochroną, to godło. Przedstawia

13 W. Duch, Mateusz Staroń: Surge Polonia to pierwsza na świecie marka odzieży patriotycznej, http://historia.org.pl/2013/03/01/surge-polonia-wywiad/ (dostęp: 4 czerwca 2017).

14 Ustawa z dnia 31 stycznia 1980 r. o godle, barwach i hymnie Rzeczypospolitej Polskiej oraz o pieczęciach państwowych, Dz.U. z 2016 r., poz. 625, s. 3. 
białego orła w złotej koronie na czerwonym tle, z głową skierowaną w prawą stronę oraz rozwiniętymi skrzydłami. Jego dziób i szpony są koloru złotego. W myśl ustawy Rada Ministrów w drodze rozporządzenia określa wzory i wymiary oficjalnych tablic z godłem, jak również sposób ich umieszczania na wskazanych obiektach oraz strojach sportowych reprezentacji ${ }^{15}$.

Innym popularnym motywem wykorzystywanym w trendach modowych jest orzeł, który nawiązuje do wydarzeń z historii Polski. Symbolizuje on siłę, wytrwałość i dumę. Jego wizerunek przywołuje dzieje narodu, będące synonimem wielkości państwa oraz jego jedności rozumianej w kontekście siły i potęgi.

Jako symbol Polski Walczącej znak kotwicy pojawił się na warszawskich murach w 1942 roku podczas drugiej wojny światowej. Był efektem konspiracyjnych działań koordynowanych przez Biuro Informacji i Propagandy Komendy Głównej Związku Walki Zbrojnej - Armii Krajowej, które skupiało się na realizowaniu akcji zbrojnych, dywersji oraz kolportażu ulotek i prasy przez Szare Szeregi.

Okoliczności powstania kotwicy nie są do końca znane. W 1974 roku nieco światła na genezę znaku Polski Walczącej rzucił Czesław Michalski. Był jednym z inicjatorów rozpisanego w 1942 roku konkursu na narodowy znak walki o niepodległość i przewodniczącym konkursowego jury. W ocenie prac brano pod uwagę wymowę patriotyczną, łatwość zrozumienia dla Polaków oraz prostotę wykonania. Już wtedy wiedziano, że symbol będzie umieszczany na murach w pośpiechu — nie tylko przez organizacje sabotażowe, ale $\mathrm{w}$ przyszłości także przez osoby niezwiązane $\mathrm{z}$ konspiracyjną walką. $\mathrm{Z}$ dwudziestu siedmiu zgłoszonych anonimowych prac wybrano kotwicę, która według jurorów była najbardziej czytelną formą wskrzeszenia narodu. Łączyła w sobie Polskę - litera „P” z walką - litera „W”. Litery złączone na kształt kotwicy symbolizowały nadzieję. Drogą podziemnych kontaktów uzyskano informację, że współautorką zwycięskiego projektu była Anna Smoleńska, pseudonim „Hanka” — studentka historii sztuki oraz instruktorka harcerska. Symbol kotwicy był malowany w widocznych miejscach, na przykład na pomniku Lotnika w Warszawie, na elewacjach urzędów lub niemieckich koszar w celu osłabienia morale agresora ${ }^{16}$. Znak dodawał Polakom otuchy oraz nie pozwalał Niemcom zapomnieć, wręcz przypominał im o ciągłym oporze ciemiężonego narodu.

W 2014 roku weszła w życie Ustawa o ochronie Znaku Polski Walczącej ${ }^{17}$. W artykule 1 wskazano, że symbol stanowi dobro ogółu członków narodu i jest atrybutem walki Polaków z niemieckim agresorem w trakcie drugiej wojny światowej. Przedstawiono dokładny opis ułożenia liter „P” „ „W” w kształt kotwicy. Artykuł 2 wspomina też o obowiązku obywateli Rzeczypospolitej Polskiej otaczania go czcią i szacunkiem.

15 Ibidem, s. 1-3.

16 A. Gładkowski, Kotwica Walcząca. Warszawskie Termopile 1942-1945, Warszawa 2015, s. 8, $21-22,28,39$.

17 Ustawa z dnia 10 czerwca 2014 r. o ochronie Znaku Polski Walczącej, Dz.U. z 2014 r., poz. 1062. 
Natomiast w artykule 3 ustawodawca wskazał, że osoba znieważająca publicznie omawiany symbol podlega karze grzywny zgodnie z przepisami zawartymi w Ustawie z dnia 24 sierpnia 2001 roku - Kodeks postępowania w sprawach o wykroczenia.

Za pierwowzór symbolu cichociemnych uważa się Znak Spadochronowy używany przez 1 Samodzielną Brygadę Spadochronową. Ciekawostką jest fakt, że ów symbol został narysowany przez Mariana Walentynowicza, który tworzył rysunki do publikacji Kornela Makuszyńskiego - autora historyjek o wędrówkach Koziołka Matołka. Znak cichociemnych powstał w 1954 roku przez dodanie do już istniejącego symbolu Polski Walczącej. Pomysłodawcami i inicjatorami tej idei byli kombatanci z Londynu ${ }^{18}$.

Za określeniem żołnierzy wyklętych kryją się członkowie różnego rodzaju organizacji podziemnych działających w Polsce w okresie 1944-1953, mimo że ich ostatni przedstawiciel zginął w 1963 roku. Głównym celem podziemnej opozycji była walka z okupantem prowadzona przede wszystkim przez mieszkańców małych wsi i miasteczek. Symbolem żołnierzy wyklętych stały się wilki - jest to nawiązanie do słów Zbigniewa Herberta: „Ponieważ żyli prawem wilka, historia o nich milczy”19.

Kolejnym często przywoływanym motywem jest husaria — jedna z najskuteczniejszych kawalerii świata. Żołnierzy tej formacji wyróżniały skrzydła przymocowywane do zbroi i wystające ponad głowę jeźdźca. Miały one wzbudzić strach wśród wrogów i spłoszyć ich konie. Liczne wygrane bitwy, na przykład pod Wiedniem, osławiły walecznych husarzy. Innym ważnym symbolem jest znak dywizji pancernej zdobiący pojazdy mechaniczne 1 Dywizji Pancernej podczas drugiej wojny światowej — szyszak oraz kojarzące się z husarią skrzydło. Wśród pomysłodawców znaku był rotmistrz Stanisław Glasser, jednak ostateczny kształt nadał mu porucznik Adam Bunsch ${ }^{20}$.

Symbol słynnego polskiego Dywizjonu 303 przeszedł do historii dzięki poświęceniu i odwadze lotników stacjonujących w Wielkiej Brytanii. Jednostka zaskakiwała Anglików swoimi umiejętnościami i skutecznością. Znak bohaterskich pilotów został wymyślony przez jednego z członków eskadry myśliwskiej, w której skład wchodzili amerykańscy ochotnicy biorący udział w walkach polsko-bolszewickich.

Znakiem Narodowych Sił Zbrojnych, konspiracyjnej organizacji polskiego ruchu narodowego, jest jaszczurka. Jest ona nawiązaniem do Związku Jaszczurczego wchodzącego w skład NSZ, a symbolizuje ideowców dążących do odbudowania znaczącej i wielkiej Polski poprzez naśladowanie cech tego zwierzęcia - zwinności, szybkości i sprytu ${ }^{21}$.

18 http://pamiec.pl/ftp/ilustracje/ZnajZnak/PDF/Karta53.pdf (dostęp: 19 czerwca 2017).

19 Ustawa z dnia 10 czerwca 2014 r. o ochronie Znaku Polski Walczącej...; Z. Herbert, Rovigo, Wrocław 1997, s. 19.

20 M. Pacut, http://www.muzeumwp.pl/emwpaedia/oznaka-rozpoznawcza-na-pojazd-1-dywizji-pancernej.php (dostęp: 27 czerwca 2017).

21 Karol Nayman: Początki narodowego Państwa Podziemnego, https://kierunki.info.pl/2015/10/ lukasz-burzynski-poczatki-narodowego-panstwa-podziemnego/ (dostęp: 27 czerwca 2017). 
Kolejnym motywem jest Miś Wojtek i odznaka 22 Kompanii Zaopatrywania Artylerii. Niezwykła historia niedźwiedzia syryjskiego przygarniętego przez żołnierzy generała Andersa do dziś inspiruje. Wychowane przez mundurowych zwierzę było maskotką 22 Kompanii Zaopatrywania Artylerii, jednak w chwili walki niedźwiedź okazał się nieocenioną pomocą dla żołnierzy. Pod Monte Cassino pełnił rolę tragarza transportującego ciężką amunicję artyleryjską. Dzięki tamtym wydarzeniom wizerunek niedźwiedzia z pociskiem w łapach stał się symbolem wspomnianej Kompanii. Ciekawostką jest, że Wojtka uznano za pełnoprawnego członka wojska. Otrzymał stopień kaprala, głównie z powodu konieczności posiadania książeczki wojskowej, dzięki której mógł wsiąść w Aleksandrii na pokład statku płynącego do Europy. Po wojnie, w trakcie demobilizacji, trafił do ogrodu zoologicznego w Edynburgu. Tam do końca swoich dni był odwiedzany przez kompanów z II Korpusu Polskiego ${ }^{22}$. Obecnie znak obrazujący niedźwiedzia Wojtka niosącego amunicję można podziwiać nie tylko na odzieży, ale nawet na etykiecie browaru czy stronach komiksu, którego był głównym bohaterem. Dzięki staraniom organizacji Wojtek Memorial Trust w 2015 roku w centrum Edynburga odsłonięto pomnik niedźwiedzia ${ }^{23}$.

\section{Działalność firm — zysk czy (również) CSR?}

Red is Bad oraz Surge Polonia należą do najbardziej znanych marek produkujących odzież patriotyczną. Niezaprzeczalnie osiągnęły komercyjny sukces związany z popularnością ubrań i akcesoriów tożsamościowych wśród części polskiego społeczeństwa. Czy w ślad za rosnącymi zyskami płynącymi ze sprzedaży produktów idzie również chęć niesienia pomocy lub krzewienia postaw patriotycznych? Wszystko wskazuje na to, że tak.

W ramach prowadzenia działań z zakresu społecznej odpowiedzialności biznesu (z ang. Corporate Social Responsibility - CSR) została powołana Fundacja Red is Bad. Jej aktywność doskonale wpisuje się w odpowiedzialność przedsiębiorstwa przede wszystkim na jednym z trzech podstawowych poziomów koncepcji 3E, to jest etyki. Zamysł firmy zaangażowanej społecznie polega głównie na dobrowolnym włączaniu do prowadzonego biznesu potrzeb wybranej grupy społecznej. Firma Red is Bad poprzez zaangażowanie $\mathrm{w}$ działalność non profit osiąga wiele korzyści, między innymi zaufanie beneficjentów, aprobatę klientów marki i zwiększenie ich lojalności, głębszą współpracę z konkretnymi środowiskami lokalnymi, kontrahentami czy organiza-

22 M. Zimmerman, Wojtek od Andersa, czyli kapral na czterech łapach, 2014, http://wiadomosci. onet.pl/kiosk/wojtek-od-andersa-czyli-kapral-na-czterech-lapach/sknr5 (dostęp: 18 czerwca 2017).

23 Miś Wojtek z Armii Andersa uhonorowany. Legendarny polski „żołnierz” ma swój pomnik w Edynburgu, http://www.tvp.info/22543742/mis-wojtek-z-armii-andersa-uhonorowany-legendarny-polskizolnierz-ma-swoj-pomnik-w-edynburgu (dostęp: 18 czerwca 2017). 
cjami pozarządowymi. Ważnym punktem rozpatrywania pozytywnych aspektów udzielania pomocy przez brand jest przede wszystkim kształtowanie pozytywnego wizerunku marki oraz budowa przewagi konkurencyjnej nad podobnymi firmami.

Podstawowym założeniem powstałej w 2016 roku Fundacji Red is Bad jest pomoc materialna żyjącym żołnierzom wyklętym i kombatantom drugiej wojny światowej. Rozpoczęcie działalności instytucji związane jest z postacią 92-letniego majora Włodzimierza Bystrzyckiego, pseudonim „Dzielny”. Mężczyzna znajdował się w ciężkiej sytuacji finansowej, o której pracowników jednego z warszawskich sklepów marki poinformował nauczyciel historii z Poznania. Ci, przejęci losem byłego żołnierza, postanowili udzielić mu pomocy. Sprawę opisano na oficjalnym profilu sklepu w serwisie społecznościowym Facebook. Zainteresowanie udzieleniem wsparcia majorowi przez osoby prywatne było tak duże, że właściciele firmy postanowili stworzyć fundację wypłacającą dożywotnie świadczenia bohaterom w potrzebie ${ }^{24}$. W akcję Przywracamy godność bohaterom zaangażowało się wiele instytucji i firm (jej partnerami są między innymi PKO Bank Polski, Agencja Rozwoju Przemysłu S.A., Fundacja Łączka czy POLREGIO Przewozy Regionalne) ${ }^{25}$.

Jeszcze nim powołano do życia Fundację, marka Red is Bad angażowała się w wiele akcji społecznych, aktywnie wspierała projekty edukacyjne (lekcje tematyczne, spotkania autorskie), fundowała nagrody w konkursach historycznych oraz zawodach sportowych promujących pamięć o ważnych wydarzeniach z historii Polski. Aktywność firmy koncentruje się jednak w głównej mierze wokół tematyki żołnierzy wyklętych.

Wspieraniem organizacji i inicjatyw patriotycznych zajmuje się również marka Surge Polonia. Na swojej stronie internetowej informuje o zaangażowaniu w popularyzację krwiodawstwa i wspieranie honorowych dawców krwi, za co otrzymała medal Serce Legionu. Rozpoczęła również kooperację ze stowarzyszeniem Wiosna, które odpowiada za charytatywny projekt Szlachetna Paczka, polegający na udzielaniu pomocy najuboższym rodzinom. Według wrocławskiej firmy udział w tym przedsięwzięciu to okazja do zademonstrowania patriotyzmu, który powinien przejawiać się $\mathrm{w}$ chęci niesienia pomocy innym ${ }^{26}$.

\section{Inflacja symboli narodowych we współczesnej Polsce}

Historyczna spuścizna przodków dziś zdobi nie tylko ubrania i akcesoria kibiców sportowych, ale także gadżety i przedmioty wykorzystywane w codziennym życiu. Niestety, dość powszechnym zjawiskiem w ostatnich latach stało się ich umieszcza-

\footnotetext{
24 https://www.redisbad.pl/fundacja-red-is-bad (dostęp: 17 czerwca 2017).

25 http://fundacja.redisbad.pl (dostęp: 17 czerwca 2017).

26 https://surgepolonia.pl/blog-pol.phtml (dostęp: 17 czerwca 2017).
} 
nie na rzeczach, które deprecjonują narodowe barwy i znaki. Gdzie zatem przebiega granica wykorzystywania symboli patriotycznych?

Nie wszystkie przedmioty życia codziennego są dobrym materiałem do manifestacji patriotyzmu. Obudowa smartfonu ze znakiem symbolizującym walkę z niemieckim okupantem, ozdobienie samochodu naklejką z tym symbolem czy produkcja kijów baseballowych opatrzonych emblematem Polski Walczącej lub wizerunkiem małego powstańca - to tylko wybrane przykłady deprecjacji ważnych dla Polaków symboli, ale również ścieżka prowadząca ku zmianie ich w znak przemocy i agresji.

Symbole bywają uwikłane w katastrofy polityczne. Skrajnym przykładem wątpliwego przewartościowania symbolu o pozytywnej przez tysiąclecia tradycji jest sprofanowany przez faszyzm znak swastyki, którą w Indiach w I i II wieku p.n.e. interpretowano jako symbol szczęścia, a w buddyzmie jako symbol klucza do raju ${ }^{27}$. W późniejszym okresie był używany przez rzymskie legiony jako znak potęgi, by w końcu stać się symbolem nazizmu — zakazanym po drugiej wojnie światowej przez prawo międzynarodowe.

Polskie motywy narodowe i historyczne są umieszczane na bieliźnie czy wycieraczkach do butów. Innym przykładem wyraźnego obniżania wartości symbolu narodowego jest wykorzystywanie barw narodowych w celu promocji browarów piwnych. Każdorazowo przy okazji zbliżających się ważnych wydarzeń sportowych w sprzedaży pojawiają się wyroby alkoholowe, do których dodawane są flagi eksponujące hasło i markę piwnego producenta. Choć artykuł 15 Ustawy o godle, barwach i hymnie Rzeczypospolitej Polskiej oraz o pieczęciach państwowych mówi jasno o zachowaniu należytej czci i szacunku wobec godła i barw narodowych, a kolejny artykuł tejże ustawy wskazuje na zakaz lokowania symboli na towarach kierowanych do obrotu handlowego, ustęp 2 tego punktu precyzuje stwierdzenie o wyrażenie zgody na umieszczanie na produktach handlowych barw narodowych i godła jako form stylizowanych albo przetworzonych w sposób artystyczny ${ }^{28}$.

Jednym z zagrożeń płynących z nadmiernego i niestosownego wykorzystywania symboliki patriotycznej, na przykład przez środowiska kibicowskie, jest utożsamianie z tymi grupami przypadkowych osób, które prezentują na odzieży symbole narodowe i patriotyczne. Przez te działania wspomniane grupy społeczne mają znaczny wpływ na kreowanie ogólnego wizerunku osób noszących odzież i akcesoria patriotyczne, a co za tym idzie - manipulację pamięcią historyczną. W związku z powyższym duża część społeczeństwa zaczyna kojarzyć klientów marek patriotycznych ze stereotypem „kibola” spędzającego wolny czas pod blokiem z piwem w ręku, eksponującego swoje przywiązanie do tradycji i historii narodu bez głębszej wiedzy czy refleksji na ich temat.

27 Leksykon symboli, red. R. Jarosiński, Warszawa 1991, s. 154.

28 Dz.U. z 2016 r., poz. 625, s. 6-7. 
Należy zwrócić szczególną uwagę na swego rodzaju stygmatyzację patriotyzmu, rozumianego jako odrzucanie lub ograniczanie kontaktów z osobami używającymi symboliki w celu eksponowania własnych poglądów. Można przyjąć, że stopniowanie wartości, polegające na określeniu, kto jest lepszym, a kto gorszym patriotą, zaczyna być dość powszechne. Rodzaj wykorzystywanych w stylizacjach znaków czy ilustracji albo liczba gadżetów przesiąkniętych tematyką patriotyczną stanowią wskaźnik przywiązania patrioty do historii i tradycji. W sytuacji, w której poza prawicową odzieżą tożsamościową pojawia się ta prezentująca lewicowy obraz historii, istnieje ryzyko kolejnego dysonansu w społeczeństwie.

Drugim niebezpieczeństwem związanym z trendem noszenia odzieży i akcesoriów patriotycznych jest niski poziom wiedzy konsumentów na temat gloryfikowanych symboli. Kondycja świadomości historycznej wśród omawianej grupy społecznej jest w tym momencie kluczowa. O spadku wartości symboli mówił Jan Ołdakowski - Dyrektor Muzeum Powstania Warszawskiego, określając zakładanie powstańczej opaski nie jako oddanie hołdu walczącym, ale raczej przywłaszczenie sobie do niej praw, rodzaj uzurpacji. Nie sposób nie zgodzić się w tej kwestii, gdyż w czasach powstania warszawskiego biało-czerwony skrawek materiału zakładany na ramię był jedynym symbolem przynależności walczących, spełniając również rolę namiastki munduru. Dyrektor Ołdakowski podkreśla, że w pełni rozumie zdecydowane stanowisko powstańców warszawskich, którzy wyrażają swój sprzeciw wobec takiej manifestacji więzi z nimi. Póki żyją, ten znak powinien być zachowany tylko dla nich. Wytatuowania sobie kotwicy Polski Walczącej i zakładania opaski nie można rozpatrywać jako wyrazu szacunku, ponieważ kombatanci tak tego nie odbierają. Na szczególną uwagę zasługują słowa mężczyzny o niegodnym użyciu znaku, w który zaopatrują się ludzie głoszący nienawistne hasła wobec innych. Przemoc, którą stosują z opaską nałożoną na ramię, staje się znacznie gorsza, ponieważ siłą rzeczy utożsamia się ją z dramatycznymi wydarzeniami drugiej wojny światowej. W takim wypadku lepiej byłoby, aby manifestujący nie nakładali powstańczej opaski. W końcu jest ona wymownym znakiem sprzeciwu wobec agresji, a także symbolem poświęcenia i ofiary ${ }^{29}$.

W krytyczny sposób do nadużywania patriotycznej symboliki odnieśli się żołnierze z Jednostki Wojskowej Komandosów w Lublińcu, angażując się w kampanię społeczną Polska Walcząca. Upamiętniaj godnie. Wspólnie z Muzeum Powstania Warszawskiego, Filmoteką Narodową oraz Kinoteką nagrali spot ilustrujący to, na czym polega szacunek do powstańczej kotwicy. Bohater krótkiego filmu jest komandosem, który znak nosi wyłącznie wtedy, gdy pełni obowiązki służbowe, a nie podczas zakupów czy w barze. Podkreśla, że nie nosi jej dla zabawy, a jego jednostka jako spadkobierca batalionów AK kontynuuje tradycje operacji specjalnych i bohaterstwa,

29 E. Dłużewska, M. Wybieralski, Powstanie warszawskie. Jan Ołdakowski: Zakładanie opasek to nie hołd, http://warszawa.wyborcza.pl/warszawa/1,150427,20468774,powstanie-warszawskie-jan-oldakowski-zakladanie-opasek-to.html (dostęp: 20 czerwca 2017). 
a nie agresji i ulicznych burd. Celem filmu promującego kampanię społeczną jest zwrócenie uwagi Polaków na niewłaściwe korzystanie z symboli narodowych, na przykład w kontekście ulicznej agresji i codziennych czynności ${ }^{30}$.

Przed nadmiernym wykorzystywaniem symboli narodowych przestrzega także właścicielka sklepu Sortmund, Joanna Pieniążek-Basta. Sklep zaopatruje służby mundurowe wszystkich rodzajów w odzież, obuwie, akcesoria. Prowadzi przy okazji kampanię Symbole narodowe. Dostrzegamy, szanujemy, informujemy, mającą na celu przedstawienie symboli oraz sposobów ich prezentowania i wykorzystywania. Akcja wskazuje również na odwieczną obecność symboliki w historii i kulturze, nakłaniając zarazem do szerzenia szacunku wśród obywateli wobec flagi, godła i hymnu ${ }^{31}$.

\section{Zakończenie}

Jak przekonują wykonane przez autorkę badania ankietowe, osoby noszące odzież i dodatki z symbolami narodowymi zazwyczaj chcą zamanifestować swoją przynależność narodową, patriotyzm oraz szacunek i przywiązanie do państwa. Noszenie odzieży patriotycznej w dużej mierze wynika zatem z poglądów politycznych, ale jest również wyrazem mody. Nie zawsze wiąże się ono z aktywnością, przejawiającą się chociażby większym zainteresowaniem historią narodu czy też wspieraniem organizacji pozarządowych, zajmujących się utrwalaniem wiedzy o historii Polski i Polaków lub pomocą kombatantom i rodakom na Wschodzie (na przykład na Kresach).

Symbolika historyczna nacechowana znamionami wielkich dokonań wykorzystywana jest w kreatywny sposób przez designerów, przez co mamy do czynienia z prawdziwą eksplozją mody na patriotyzm. Firmy, takie jak omawiane Red is Bad oraz Surge Polonia, swój biznes zaczęły od fascynacji historią Polski i w ten sposób symbolika przeniknęła do wzornictwa przemysłowego. Nadzieję na wzrost świadomości społeczeństwa daje rozszerzenie kręgu działań z zakresu edukacji obywatelskiej. Jej rola w społeczeństwie jest nie do przecenienia. Jednym z elementów pobudzenia aktywności jest opracowywany przez Ministerstwo Kultury i Dziedzictwa Narodowego Program Wieloletni NIEPODLEGŁA na lata 2017-2021, a także zapowiadane działania państwa oraz różnych podmiotów, koncentrujące się wokół kreowania mody na wiedzę o Polsce. Projekt jest związany z obchodami stulecia odzyskania przez Polskę niepodległości, która w 1918 roku, po 123 latach politycznego niebytu, powróciła na mapę Europy.

30 A. Kielar, Akcja „Upamiętniaj godnie”, http://www.politykawarszawska.pl/index.php/article/1834 (dostęp: 20 czerwca 2017).

31 Symbole narodowe, http://www.sortmund.pl/Symbole-Narodowe-cabout-pol-45.html (dostęp: 20 czerwca 2017). 
Wzmocnieniu poczucia wspólnoty Polaków służyć mają projekty ogólnopolskie polegające na realizowaniu wysokiej jakości zadań upamiętniających stulecie odzyskania niepodległości. MKiDN uruchomi również programy zasilające finansowo realizację przedsięwzięć regionalnych mających na celu włączenie obywateli we współtworzenie obchodów oraz realizację inicjatyw międzynarodowych, których priorytetem będzie upowszechnianie opartego o naczelne dla Polaków wartości wizerunku ojczyzny.

\section{Selected examples of commercialization of symbols of national and patriotic significance in Poland}

\section{Summary}

In recent years, there has been a noticeable increase in interest in patriotic or national clothing and accessories. The use of specific symbols that have a historical heritage is interpreted in different, often extreme ways. The author attempted to analyze this phenomenon, not only in terms of the possible depreciation of national symbols. In this paper the author will briefly present the results of research conducted for an unpublished master's thesis in 2017 on people wearing identity clothing. 